\title{
Optimisation of Process Parameters in Kenaf/Polypropylene Composites in Connection Moulding
}

\author{
R.Varadaraju, J.Srinivasan
}

\begin{abstract}
Renewable natural fibres like kenaf can be used to produce composites as replacement to plastic boards in household and industrial applications. The objective of this study is to optimise the process parameters for compression moulding of kenaf polypropylene composite to get maximum tensile, flexural and impact strength values for three different blend ratios. Three levels of temperature $(1600 \mathrm{C}, 180 \mathrm{oC}$ and $200 \mathrm{oC})$, compression pressure $(7,9$ and $11 \mathrm{Mpa})$ and time of application (10,20 and 30 min ) for producing kenaf/ polypropylene blend ratios of 50:50, 65:35 and 80:20 have been used. The samples were produced through carding for web formation, needle punching for non woven making and finally in compression moulding machine for boards making. All the composite boards were analysed for tensile, flexural and impact strength. The tensile and flexural strengths have positive correlations with time and temperature and contact pressure in all the blend ratios kenaf / polypropylene. The impact strength has positive correlation with time, temperature whereas it has negative correlation with contact pressure in all the blend ratios. The highest tensile strength and flexural strength is achieved with 65:35 kenaf / polypropylene blend at 200 o $C$ temperature, $11 \mathrm{Mpa}$ pressure and 10 minutes duration in compression moulding machine. The highest Impact strength is achieved with 80:20 blends at 180 o C, 7 Mpa pressure and 30 minutes duration. The tensile and flexural strength is the highest at the blend ratio of 65:35 whereas the Impact strength increases with the increase kenaf content up to $80 \%$..
\end{abstract}

Keywords-tensile strength, flexural strength, impact strength, temperature, pressure, time, natural fibre

\section{INTRODUCTION}

The main merits and demerits of natural fibre composites [1-5) are given below: The main merits are lower density and higher specific strength, stiffness, obtained from renewable resource, consuming little energy, carbon dioxide absorption, emission of oxygen to the atmosphere lower hazard in the production processes, lesser manufacturing cost. The main demerits are lower service life, higher water absorption causing swelling, lower impact strength, higher variability in composite properties

\section{LITERATRE SURVEY}

The mechanical performance of NFCs are affected by the fibre properties, matrix properties, strength of fibre matrix interface, extend of dispersion of fibre, the orientation of fibre, production process and porosity. The choice of natural fibres for making composites are based on its availability in the particular country [7].In Asian countries hemp, kenaf,

Revised Manuscript Received on July 18, 2019.

R.Varadaraju, Deaptment of Fashion Technology Kumaraguru college of Technology Coimbatore,India.(E-mail: rvraju23@yahoo.co.in)

J.Srinivasan, Deaptment of Textile Technology Kumaraguru college of Technology Coimbatore,India. (E-mail:.srinivasan.j.ft@kct.ac.in) jute and sisal are available in plenty whereas flax is available in Europe and Harakeke fibre is available in New Zealand [7]. It was reported that jute and hollow conjugated polyester reinforced non woven composite of 50:50 ratio is suitable for structural materials of building [6] furniture making [8] outdoor \& indoor insulation applications [9].Longer fibres can take up higher loads but too longer fibres may entangle during mixing and result in lower reinforcement [14-16].The length to diameter ratio of the fibre affects the mechanical properties. The fibre length must be higher than the critical length for the fibre to be broken during tensile load application in a composite [12].For efficient reinforcement fibre length must be much higher. Even though thermoplastic and thermo set plastics can be used as matrix for making natural fibre composites [17] mostly polypropylene, polyvinyl chloride and polyethylene are used because of their lower softening temperature below $200^{\circ} \mathrm{C}$ whereas natural fibres degrades above $200^{\circ} \mathrm{C}$ [18], thermoplastics can be repeatedly softened and can also be recycled.PLA gives higher strength and stiffness among the bio derived matrix materials.

Good interfacial binding is required to achieve good reinforcement, fibre wetting is the pre requisite for good bonding [19, 20] toughness, tensile and flexural strength. Mechanical interlock, chemical bonding, electrostatic bonding and inter diffusion bonding are the mechanisms of interfacial bonding [13].Good dispersion reduces voids for ensuring that fibres are fully surrounded by the matrix [22] and gives good interfacial strength. Time, temperature, pressure, additives and fibre surface modifications are the factors that affects dispersion [21].Parallel alignment of fibres to the direction of load application improves the mechanical properties of the composites [11,23-26]. Compression moulding is used for thermoplastic matrix. Time, temperature, pressure, and matrix viscosity [27] are the factors that affect the properties of composites in compression moulding. Film stacking is also done to reduce fibre degradation [28]. The optimum temperature for good mechanical properties is $150^{\circ} \mathrm{C}$ for flax/polyester amide composites [29], $180^{\circ} \mathrm{C}$ for jute [1] and $200^{\circ} \mathrm{C}$ for nonwoven mat reinforced with polypropylene [30].Porosity increases more rapidly with the increase in the proportion of fibres in composites after the limit to compact. In Flax/ polypropylene composites the porosity increases from 4 to 8 volume $\%$ as the fibre proportion increases from $56 \%$ to $72 \%$ 


\section{OPTIMISATION OF PROCESS PARAMETERS IN KENAF/POLYPROPYLENE COMPOSITES IN CONNECTION MOULDING}

[12].With non-woven fabric containing polypropylene and kenaf, we can achieve higher proportion of fibre than stacked composites and also to give higher impact strength $[10,11]$ higher biodegradability. In a study with $6 \mathrm{~mm}$ layer composite with kenaf/ polypropylene blend ratio of 50:50 it was reported that temperature and time in compression moulding are main factors influencing the properties of composite [31]. $230^{\circ} \mathrm{C}$ temperature and 120 second duration was found to give higher tensile and flexural modulus whereas $200{ }^{\circ} \mathrm{C}$ and 60 seconds was found to give higher Impact strength in layered composite with kenaf/ polypropylene [31]

The literature review revealed that not much detailed studies were available on the effect of processing parameters in compression moulding machine to produce kenaf polypropylene fibre non woven composite on tensile, flexural and impact strength values for different blend ratios.

\section{A Objectives}

The objective of this study is (1)To investigate the influence of temperature, time of application and compression pressure of applied in compression moulding machine to produce kenaf polypropylene composite on tensile, flexural and impact strength values for different blend ratios. (2) To decide the most suitable kenaf/ polypropylene blend ratio to achieve the highest tensile, flexural and impact strength values.

\section{EXPERIMENTAL}

\section{A Method}

Twenty seven kenaf/ polypropylene composite boards in each of three blend ratios were produced with variations in its processing parameters. (temperature, time and compression pressure); They were tested for their tensile, flexural and impact strength;The influence of processing parameters on its properties were analysed and also developed the regression equations for each of the tensile, flexural and impact strength from its processing parameters for the three blend ratios. Kenaf/ polypropylene blends in the ratios of 50: 50, 65:35 and 80:20 were selected for the study.

\section{B Materials}

The kenaf fibre of $30 \mathrm{~mm}$ length and polypropylene fibre of $32 \mathrm{~mm} * 1.5$ denier were selected for the study. The above fibres were blended in the weight ratios of 50: 50, 65:35 and $80: 20$ and made into web for random dispersion of fibres. The web formed in the carding machine was needle punched to make it compact non woven material of $6.5 \mathrm{~mm}$ thickness to ensure that a controlled composite boards of $3 \mathrm{~mm}$ thickness can be produced. The non woven material of $30 \mathrm{~cm} * 30 \mathrm{~cm}$ was processed in a compression moulding machine (Velan Engineering, India) to produce boards of $3 \mathrm{~mm}$ thickness. The composite boards were cut into required size depending upon the type of test. Three levels of Temperature $\left(160{ }^{\circ} \mathrm{C}, 180^{\circ} \mathrm{C}\right.$ and $200{ }^{\circ} \mathrm{C}$ ), compression pressure $(7,9$ and $11 \mathrm{Mpa})$ and time of application $(10,20$ and $30 \mathrm{~min}$ ) for producing kenaf/ polypropylene blend ratios of 50:50, 65:35 and 80:20 have been used.

The non woven materials are chosen for making the composite because of the following reasons: There are more overlapping area between the fibre and polymer matrix; higher fraction up to $80 \%$ of kenaf can be used which improves the biodegradability of the composite; the structure will be more porous with higher kenaf fraction which absorbs impact loads and sound; random distribution of kenaf/ polypropylene fibres which makes the fibres bind together with the help of polypropylene melt as glue.

\section{Testing of fabric properties}

All the samples under study were tested All the composite boards were tested for tensile strength (ASTM 638-90); flexural strength (ASTM D 790-90) in universal strength testing machine and impact strength (ASTM D4812) were tested in charpy impact pendulum strength tester under standard atmospheric conditions of $65 \pm 0.5 \%$ relative humidity and $27 \pm 0.2{ }^{\circ} \mathrm{C}$ Ten readings were taken in each type of test and blend ratio for calculating the average of the properties

\section{Statistical Analysis}

The analysis of data was done using MINI TAB 14 (Minitab Inc., State College, Pennsylvania) statistic software for analysis for variance and regression.

\section{RESULTS}

The tensile strength, flexural strength and impact strength of kenaf/ polypropylene composites in the blend ratios of 50: 50, 65:35 and 80:20 for three levels of Temperature $\left(160{ }^{\circ} \mathrm{C}, 180^{\circ} \mathrm{C}\right.$ and $\left.200{ }^{\circ} \mathrm{C}\right)$, compression pressure $(7,9$ and $11 \mathrm{Mpa}$ ) and time of application (10,20 and $30 \mathrm{~min}$ ) for producing in compression moulding are given in Table I. The analysis of variance (ANOVA) of the results and the response regression coefficients of temperature, time and pressure for tensile strength, flexural strength and impact strength are given in Tables II and III.

TABLE I. MECHANICAL PROPERTIES OF KENAF: POLYPROPLENE COMPOSITE OF DIFFERENT BLEND RATIOS

\begin{tabular}{|c|c|c|c|c|c|c|c|c|c|}
\hline \multirow[t]{2}{*}{$\begin{array}{c}\text { Temperature }\left(^{\circ}\right. \\
\text { C)/ } \\
\text { Time }(\min ) / \\
\text { Pressure(Mpa) }\end{array}$} & $\begin{array}{c}\text { Tensile } \\
\text { Strength } \\
\text { (Mpa) }\end{array}$ & $\begin{array}{c}\text { Flexura } \\
1 \\
\text { Strengt } \\
\text { h (Mpa) }\end{array}$ & $\begin{array}{c}\text { Impact } \\
\text { Strengt } \\
\mathbf{h} \\
\left(\mathrm{KJ} / \mathbf{m}^{2}\right)\end{array}$ & $\begin{array}{c}\text { Tensile } \\
\text { Strengt } \\
\text { h (Mpa) }\end{array}$ & $\begin{array}{c}\text { Flexura } \\
1 \\
\text { Strengt } \\
\text { h (Mpa) }\end{array}$ & $\begin{array}{c}\text { Impact } \\
\text { Strengt } \\
\mathbf{h} \\
\left(\mathbf{K J} / \mathbf{m}^{2}\right)\end{array}$ & $\begin{array}{r}\text { Tensile } \\
\text { Strengt } \\
\text { h (Mpa) }\end{array}$ & $\begin{array}{c}\text { Flexural } \\
\text { Strength } \\
\text { (Mpa) }\end{array}$ & $\begin{array}{c}\text { Impact } \\
\text { Strengt } \\
\mathbf{h} \\
\left(\mathrm{KJ} / \mathbf{m}^{2}\right)\end{array}$ \\
\hline & \multicolumn{3}{|c|}{ Kenaf/PP 50: 50 blend } & \multicolumn{3}{|c|}{ Kenaf/PP 65:35 blend } & \multicolumn{3}{|c|}{ Kenaf/PP 80:20 blend } \\
\hline $180 / 10 / 7$ & 110 & 78 & 3.9 & 136.5 & 98.7 & 6.3 & 115.93 & 86.59 & 11.03 \\
\hline
\end{tabular}


International Journal of Innovative Technology and Exploring Engineering (IJITEE) ISSN: 2278-3075, Volume-8, Issue- 9S2, July 2019

\begin{tabular}{|c|c|c|c|c|c|c|c|c|c|}
\hline $180 / 20 / 7$ & 122 & 85 & 4.49 & 156.98 & 113.51 & 7.25 & 133.32 & 99.58 & 15.44 \\
\hline $180 / 30 / 7$ & 125 & 88 & 4.29 & 150.15 & 108.57 & 6.93 & 127.53 & 95.25 & 16.54 \\
\hline $160 / 10 / 7$ & 90 & 63 & 2.6 & 110.11 & 78.96 & 4.2 & 91.09 & 68.92 & 5.51 \\
\hline $160 / 20 / 7$ & 100 & 70 & 2.99 & 126.63 & 90.8 & 4.83 & 104.75 & 79.26 & 8.82 \\
\hline $160 / 30 / 7$ & 103 & 72 & 2.99 & 126.63 & 90.8 & 4.83 & 104.75 & 79.26 & 9.92 \\
\hline $200 / 10 / 7$ & 135 & 91 & 3.9 & 174.72 & 126.9 & 6.3 & 132.5 & 97.2 & 6.62 \\
\hline $200 / 20 / 7$ & 150 & 105 & 3.71 & 165.98 & 120.56 & 5.99 & 125.87 & 92.34 & 12.13 \\
\hline $200 / 30 / 7$ & 155 & 108 & 3.51 & 157.25 & 114.21 & 5.67 & 119.25 & 87.48 & 12.13 \\
\hline $180 / 10 / 9$ & 112.2 & 79.56 & 4.1 & 150 & 105 & 6 & 127.4 & 92.12 & 10.5 \\
\hline $180 / 20 / 9$ & 124.44 & 86.7 & 4.71 & 172.5 & 120.75 & 6.9 & 146.51 & 105.94 & 14.7 \\
\hline $180 / 30 / 9$ & 127.5 & 89.76 & 4.5 & 165 & 115.5 & 6.6 & 140.14 & 101.33 & 15.75 \\
\hline $160 / 10 / 9$ & 91.8 & 64.26 & 2.73 & 121 & 84 & 4 & 100.1 & 73.32 & 5.25 \\
\hline $160 / 20 / 9$ & 102 & 71.4 & 3.14 & 139.15 & 96.6 & 4.6 & 115.12 & 84.32 & 8.4 \\
\hline $160 / 30 / 9$ & 105.06 & 73.44 & 3.14 & 139.15 & 96.6 & 4.6 & 115.12 & 84.32 & 9.45 \\
\hline $200 / 10 / 9$ & 137.7 & 92.82 & 4.1 & 192 & 135 & 6 & 145.6 & 103.4 & 6.3 \\
\hline $200 / 20 / 9$ & 153 & 107.1 & 3.89 & 182.4 & 128.25 & 5.7 & 138.32 & 98.23 & 11.55 \\
\hline $200 / 30 / 9$ & 158.1 & 110.16 & 3.69 & 172.8 & 121.5 & 5.4 & 131.04 & 93.06 & 11.55 \\
\hline 180/10/11 & 113.32 & 80.36 & 3.85 & 154.5 & 108.15 & 5.92 & 140 & 98 & 10 \\
\hline $180 / 20 / 11$ & 125.68 & 87.57 & 4.43 & 177.68 & 124.37 & 6.81 & 161 & 112.7 & 14 \\
\hline $180 / 30 / 11$ & 128.78 & 90.66 & 4.23 & 169.95 & 118.97 & 6.51 & 154 & 107.8 & 15 \\
\hline 160/10/11 & 92.72 & 64.9 & 2.57 & 124.63 & 86.52 & 3.95 & 110 & 78 & 5 \\
\hline $160 / 20 / 11$ & 103.02 & 72.11 & 2.95 & 143.32 & 99.5 & 4.54 & 126.5 & 89.7 & 8 \\
\hline $160 / 30 / 11$ & 106.11 & 74.17 & 2.95 & 143.32 & 99.5 & 4.54 & 126.5 & 89.7 & 9 \\
\hline $200 / 10 / 11$ & 139.08 & 93.75 & 3.85 & 197.76 & 139.05 & 5.92 & 160 & 110 & 6 \\
\hline $200 / 20 / 11$ & 154.53 & 108.17 & 3.66 & 187.87 & 132.1 & 5.63 & 152 & 104.5 & 11 \\
\hline $200 / 30 / 11$ & 159.68 & 111.26 & 3.46 & 177.98 & 125.15 & 5.33 & 144 & 99 & 11 \\
\hline
\end{tabular}

TABLE II ANALYSIS OF VARIANCE OF KENAF/POLYPROPYLENE COMPOSITE PROPERTIES

\begin{tabular}{|c|c|c|c|c|c|c|c|c|c|c|}
\hline \multirow[b]{2}{*}{ Responses } & \multicolumn{3}{|c|}{ Temperature- $^{0} \mathrm{C}\left(\mathrm{x}_{1}\right)$} & \multicolumn{3}{|c|}{ Time-min $\left(x_{2}\right)$} & \multicolumn{3}{|c|}{ Pressure (Mpa) $\left(\mathbf{x}_{\mathbf{3}}\right)$} & \multirow{2}{*}{$\begin{array}{c}\text { Error } \\
\% \\
\text { contri- } \\
\text {-bution }\end{array}$} \\
\hline & $F$ & $p$ & $\begin{array}{c}\% \\
\text { contri- } \\
\text {-bution }\end{array}$ & $\boldsymbol{F}$ & $p$ & $\begin{array}{c}\% \\
\text { contri- } \\
\text {-bution }\end{array}$ & $F$ & $p$ & $\begin{array}{c}\% \\
\text { contri- } \\
\text {-bution }\end{array}$ & \\
\hline \multicolumn{11}{|c|}{ Kenaf/PP 50: 50 blend } \\
\hline Tensile Strength (Mpa) & 24.96 & 0.001 & 87.11 & $\begin{array}{c}63.0 \\
6\end{array}$ & 0.000 & 10.74 & 2.853 & 0.000 & 0.34 & 1.82 \\
\hline $\begin{array}{c}\text { Flexural } \\
\text { Strength(Mpa) }\end{array}$ & 18.74 & 0.003 & 83.75 & $\begin{array}{c}78.1 \\
5\end{array}$ & 0.000 & 13.99 & 2.853 & 0.000 & 0.35 & 1.91 \\
\hline $\begin{array}{c}\text { Impact Strength } \\
\left(\mathrm{KJ} / \mathrm{m}^{2}\right)\end{array}$ & 24.09 & 0.001 & 84.93 & $\begin{array}{c}12.2 \\
7\end{array}$ & 0.000 & 10.13 & 10.86 & $\mathbf{0 . 0 0 0}$ & 2.45 & 2.48 \\
\hline \multicolumn{11}{|c|}{ Kenaf/PP 65:35 blend } \\
\hline Tensile Strength (Mpa) & 16.62 & 0.004 & 74.32 & $\begin{array}{c}3.17 \\
2\end{array}$ & 0.027 & 9.78 & 50.62 & 0.000 & 13.24 & 2.67 \\
\hline $\begin{array}{c}\text { Flexural } \\
\text { Strength(Mpa) }\end{array}$ & 17.98 & 0.003 & 79.03 & $\begin{array}{c}5.99 \\
3\end{array}$ & 0.001 & 11.63 & 26.75 & 0.000 & 6.73 & 2.61 \\
\hline $\begin{array}{c}\text { Impact Strength } \\
\left(\mathrm{KJ} / \mathrm{m}^{2}\right)\end{array}$ & 24.07 & 0.001 & 85.32 & $\begin{array}{c}12.3 \\
7\end{array}$ & 0.000 & 10.2 & 13.49 & 0.000 & 2.49 & 2 \\
\hline \multicolumn{11}{|c|}{ Kenaf/PP 80:20 blend } \\
\hline Tensile Stength (Mpa) & 10.6 & 0.011 & 56.81 & $\begin{array}{c}1.49 \\
3\end{array}$ & 0.236 & 5.86 & 193.36 & 0.000 & 35.49 & 1.84 \\
\hline $\begin{array}{c}\text { Flexural } \\
\text { Strength(Mpa) }\end{array}$ & 8.725 & 0.027 & 60.72 & 3.49 & 0.018 & 16.83 & 83.62 & 0.000 & 20.03 & 2.42 \\
\hline $\begin{array}{c}\text { Impact Strength } \\
\left(\mathrm{KJ} / \mathbf{m}^{2}\right)\end{array}$ & 3.78 & 0.087 & 47.29 & $\begin{array}{c}76.7 \\
8\end{array}$ & $\mathbf{0}$ & 50.37 & 52.06 & 0.000 & 1.96 & 0.38 \\
\hline
\end{tabular}




\section{OPTIMISATION OF PROCESS PARAMETERS IN KENAF/POLYPROPYLENE COMPOSITES IN CONNECTION MOULDING}

TABLE III RESPONSE REGRESSION COEFFICIENTS KENAF/POLYPROPYLENE COMPOSITE PROPERTIES

\begin{tabular}{|c|c|c|c|c|c|}
\hline \multirow{3}{*}{ Responses } & \multirow{3}{*}{$\mathbf{R}^{2} \%$} & \multicolumn{4}{|l|}{ Regression coefficients } \\
\hline & & \multirow[t]{2}{*}{ Constant(k) } & \multirow[t]{2}{*}{ Temperature- $^{0} \mathrm{C}\left(\mathrm{x}_{1}\right)$} & Time-min & $\begin{array}{l}\text { Pressure } \\
\text { (Mpa) }\end{array}$ \\
\hline & & & & $\left(\mathbf{x}_{2}\right)$ & $\left(\mathbf{x}_{3}\right)$ \\
\hline \multicolumn{6}{|l|}{ Kenaf/PP 50: 50 blend } \\
\hline Tensile Strength (Mpa) & 97.6 & -127.23 & 1.256 & 0.8 & 0.937 \\
\hline $\begin{array}{l}\text { Flexural } \\
\text { Strength(Mpa) }\end{array}$ & 97.4 & -85.3 & 0.856 & 0.588 & 0.625 \\
\hline $\begin{array}{l}\text { Impact Strength } \\
\left(\mathrm{KJ} / \mathrm{m}^{2}\right)\end{array}$ & 32.4 & -0.234 & 0.0214 & 0.0064 & -0.119 \\
\hline \multicolumn{6}{|l|}{ Kenaf/PP $65: 35$ blend } \\
\hline Tensile Strength (Mpa) & 82.4 & -108.84 & 1.2079 & 0.2279 & 4.78 \\
\hline $\begin{array}{l}\text { Flexural } \\
\text { Strength(Mpa) }\end{array}$ & 83.2 & -75.1 & 0.8873 & 0.1584 & 2.508 \\
\hline $\begin{array}{l}\text { Impact Strength } \\
\left(\mathrm{KJ} / \mathrm{m}^{2}\right)\end{array}$ & 34.7 & 0.2613 & 0.0329 & 0.0101 & -0.0872 \\
\hline \multicolumn{6}{|l|}{ Kenaf/PP 80:20 blend } \\
\hline Tensile Strength (Mpa) & 65.4 & -51.058 & 0.675 & 0.325 & 6.125 \\
\hline $\begin{array}{l}\text { Flexural } \\
\text { Strength(Mpa) }\end{array}$ & 53.6 & -12.125 & 0.419 & 0.238 & 3 \\
\hline $\begin{array}{l}\text { Impact Strength } \\
\left(\mathrm{KJ} / \mathrm{m}^{2}\right)\end{array}$ & 40.4 & -2.044 & 0.0606 & 0.261 & -0.3 \\
\hline
\end{tabular}

\section{A Regression Equations}

Equations of the form $\mathrm{y}=\mathrm{k}+\mathrm{ax}_{1}+\mathrm{bx}_{2}+\mathrm{cx}_{3}$ were formed to predict the mechanical properties from the composite processing parameters for each of the 50:50, 65:35,80:20 blend ratios and the regression coefficients of equations are given in Table III.

Where $\mathrm{x}_{1}$ is temperature; $\mathrm{x}_{2}$ is time and $\mathrm{x}_{3}$ is compression pressure which are independent variables. The regression coefficients for tensile strength $\left(R^{2}=97.6\right.$; $p<.001)$, flexural strength $\left(R^{2}=97.4 ; p<.001\right)$, and impact strength $\left(R^{2}=41.7 ; p<.001\right)$ in 50:50 blend are significant.; tensile strength $\left(R^{2}=82.4 ; p<.001\right)$, flexural strength, $\left(R^{2}=83.2 ; \quad p<.001\right) \quad$ and impact $\operatorname{strength}\left(R^{2}=34.7\right.$; $p<.001$ in $65: 35$ blend are also significant.; tensile strength $\left(R^{2}=65.4 ; p<.001\right)$, flexural strength $\left(R^{2}=53.6\right.$; $p<.001)$ and Impact strength $\left(R^{2}=40.4 ; p<.001\right)$ in $80: 20$ blend are also significant.

\section{B Error Analysis of Regression Equations for Validation}

Regression equations were tested for their validity by calculating the $\% R^{2}$ (square of correlation coefficient) values between the actual and predicted values. The root mean square deviation \% (RMSD) of predicted values actual values was also calculated and given in Table IV. The \% RMSD for tensile strength, flexural strength and impact Strength are 2,11,2,22 and 22.42 respectively in 50:50 blend; The \% RMSD for tensile strength, flexural strength and impact Strength are 4.79,4.65 and 11.70 respectively in 65:35 blend; The \% RMSD for tensile strength, flexural strength and impact Strength are 6.17,6.23 and 22.72 respectively in 80:20 blend. The deviation in impact strength is higher due to lower coefficient of determination $\left(\mathrm{R}^{2}\right)$

\section{TABLE IV \% RMSD VALUES BETWEEN PREDICTED}

AND ACTUAL VALUES

\begin{tabular}{|c|c|c|c|}
\hline Properties & $\begin{array}{l}50: 50 \\
\text { blend }\end{array}$ & $\begin{array}{l}65: 35 \\
\text { blend }\end{array}$ & $\begin{array}{l}80: 20 \\
\text { blend }\end{array}$ \\
\hline $\begin{array}{c}\text { Tensile } \\
\text { Strength }\end{array}$ & 2.11 & 2.22 & 22.42 \\
\hline $\begin{array}{c}\text { Flexural } \\
\text { Strength }\end{array}$ & 4.79 & 4.65 & 11.70 \\
\hline $\begin{array}{c}\text { Impact } \\
\text { Strength }\end{array}$ & 6.17 & 6.23 & 22.72 \\
\hline
\end{tabular}

C Influence of composite processing Parameters on Mechanical properties

1) Tensile Strength: The tensile Strength has positive correlation with time and temperature and contact pressure in all the three blend ratios. This is due to good melt formation of polypropylene which spread across the entire volume of the non woven blend material. The individual fibres are well interfaced with the adjacent fibres by polypropylene melt. The compression pressure enables good contact between fibres and polymer melt. The value $\% \mathrm{R}^{2} \%$ is 97.6 for 50:50 blend ratio, 82.4 for $65: 35$ blend ratio and 65.4 for $80: 20$ blend ratios. The coefficient of determination $\left(\mathrm{R}^{2}\right)$ reduces with the increase in kenaf content. This is due to reduced availability of polypropylene for melting and influencing. The tensile strength increases from with increase in kenaf content from $50 \%$ to $65 \%$ but drops with a further increase to $80 \%$ in all processing conditions. 
The ANOVA results show that the variance in Tensile Strength is attributed due to temperature by $87.11 \%$ $(F=24.96 ; p=0.001)$ time $10.74 \%(F=63.0687 ; p=0.000)$ and compression pressure by $0.34 \%(F=2.853 p=0.000)$ in 50:50 kenaf/polypropylene blend composite; due to temperature by $74.32 \% \quad(F=16.62 ; p=0.004)$ time by $9.78 \%(F=3.172 ; p=0.027)$ and compression pressure by $13.24 \% \quad(F=50.62 ; \quad p=0.000) \quad$ in $65: 35$ kenaf/polypropylene blend composite; due to temperature by $56.81 \%(F=10.6 ; p=0.011)$ time $5.86 \% \quad(F=1.493$; $p=0.236)$ and compression pressure by $35.49 \%$ $(F=193.36 ; p=0.000)$ in $80: 20 \mathrm{kenaf} /$ polypropylene blend composite.

2) Flexural Strength: The Flexural Strength also has positive correlation with time, temperature and contact pressure in all the three blend ratios. This is due to good melt formation of polypropylene which spread across the entire volume of the non woven blend material. The individual fibres are well interfaced with the adjacent fibres by polypropylene melt. The compression pressure enables good contact between fibres and polymer melt. The value of $\% \mathrm{R}^{2}$ is 97.4 or $50: 50$ blend ratio, 83.2 for $65: 35$ blend ratio and 53.6 for $80: 20$ blend ratio. The coefficient of determination $\left(\mathrm{R}^{2}\right)$ reduces with the increase in kenaf content. This is due reduce availability of polypropylene for melting and influencing. The flexural strength increases from with increase in kenaf content from $50 \%$ to $65 \%$ but drops with a further increase to $80 \%$ in all processing conditions.

The ANOVA results show that the variance in flexural strength is attributed due to temperature by $83.75 \%$ $(F=18.749 ; p=0.001)$ time $13.99 \%(F=78.15 ; p=0.000)$ and compression pressure by $0.35 \%(F=2.853 p=0.000)$ in 50:50 kenaf/polypropylene blend composite; due to temperature by $79.03 \% \quad(F=17.98 ; p=0.003)$ Time $11.63 \%(F=5.993 ; p=0.001)$ and compression pressure by blend composite; due to temperature by $60.72 \%$ $(F=8.725 ; p=0.027)$ time $16.83 \%(F=3.49 ; p=0.018)$ and compression pressure by $20.03 \%(F=83.62 ; p=0.000)$ in 80:20kenaf/polypropylene blend composite.

3) Impact Strength: The Impact Strength has positive correlation with time, temperature whereas it has negative correlation with contact pressure in all the three blend ratios. Binding improvement is due to good melt formation of polypropylene with the increase in temperature and time which spread across the entire volume of the non woven blend material. The increase in pressure reduces the porosity of the material and reduces the shock load absorbing capacity. The value of $\mathrm{R}^{2} \%$ is 41.7 or $50: 50$ blend ratio, 34.7 for $65: 35$ blend ratio and 40.4 for $80: 20$ blend ratios. This is due to lesser influence of processing parameters on impact strength.

The ANOVA results show that the variance in Impact strength is attributed due to temperature by $84.93 \%$ $(F=24.09 ; p=0.001)$ time $10.86 \%(F=12.27 ; p=0.000)$ and compression pressure by $2.45 \%(F=10.86 p=0.000)$ in 50:50 kenaf/polypropylene blend composite; due to temperature by $85.32 \%(F=24.07 ; p=0.001)$ Time $10.2 \%$ $(F=13.49 ; p=0.000)$ and compression pressure by $2.42 \%$ $(F=10.86 p=0.000)$ in $65: 35$ kenaf/polypropylene blend $6.73 \%(F=26.75 p=0.000)$ in 65:35 kenaf/polypropylene

composite; attributed due to temperature by $47.29 \%$ $(F=3.78 ; p=0.087)$ time $50.37 \%(F=76.78 ; p=0.000)$ and compression pressure by $1.96 \%(F=52.06 p=0.000)$ in 80:20 kenaf/polypropylene blend composite.

D Optimum composite processing parameters for higher mechanical properties

The highest tensile strength of 197.76 Mpa and flexural strength of $139.05 \mathrm{Mpa}$ is achieved with 65:35 kenaf / polypropylene blend composite at $200^{\circ} \mathrm{C}$ temperature, $11 \mathrm{Mpa}$ pressure and 10 minutes duration in compression moulding machine. The maximum tensile strength of 161 Mpa and flexural strength of $112 \mathrm{Mpa}$ is achieved in 80: 20 kenaf / polypropylene blend with $180^{\circ} \mathrm{C}$ temperature, $11 \mathrm{Mpa}$ pressure and 20 minutes duration in compression moulding machine. The maximum tensile strength of 159.7 Mpa and flexural strength of $112.26 \mathrm{Mpa}$ is achieved in 50:50 kenaf / polypropylene blend with $200^{\circ}$ $\mathrm{C}$ temperature, $11 \mathrm{Mpa}$ pressure and 30 minutes duration in in compression moulding machine. The density of polypropylene is about $0.95 \mathrm{~g} / \mathrm{cc}$ where as the density of kenaf fibre is $1.45 \mathrm{~g} / \mathrm{cc}$, Due to this density difference the volume of kenaf fibre in 65:35 blend is nearly $50 \%$ and makes good interfacial binding with polypropylene melt resulting in the highest tensile strength and flexural strength. In 50:50 blend the volume of kenaf is $40 \%$ only resulting in lower tensile strength and flexural strength whereas in80:20 blend the volume of polypropylene is only $25 \%$ which is too low to bind the kenaf fibres which resulted in lower tensile strength and flexural strength.

The highest Impact strength of $16.54 \mathrm{KJ} / \mathrm{m}^{2}$ is achieved with $80: 20$ blend composite at $180{ }^{\circ} \mathrm{C}, 7 \mathrm{Mpa}$ pressure and 30 minutes duration processing parameters in compression moulding machine. The maximum Impact strength of $7.25 \mathrm{KJ} / \mathrm{m}^{2}$ is achieved in $65: 35$ blends at $180^{\circ}$ $\mathrm{C}, 7 \mathrm{Mpa}$ pressure and 20 minutes duration the maximum impact strength of $4.49 \mathrm{KJ} / \mathrm{m}^{2}$ is achieved in 50:50 blend at $180^{\circ} \mathrm{C}, 7 \mathrm{Mpa}$ pressure and 20 minutes duration. The tensile and flexural strength are the highest at a blend ratio of 65:35 whereas the impact strength increases with the increase kenaf content up to $80: 20$. With the increase in kenaf fibre content from $50 \%$ to $65 \%$ and to $80 \%$ the porosity and cushioning effect of the composite increases which absorbs the impact load and improves the impact strength.

\section{CONCLUSIONS}

The tensile and flexural strengths have positive correlations with time and temperature and contact pressure in all the blend ratios kenaf / polypropylene. The impact strength has positive correlation with time, temperature whereas it has negative correlation with contact pressure in all the blend ratios. The highest tensile strength of $197.76 \mathrm{Mpa}$ and flexural strength of 139.05 Mpa in 65:35 kenaf / polypropylene blend is achieved with $200{ }^{\circ} \mathrm{C}$ Temperature, 11Mpa pressure and 10 minutes duration in compression moulding machine. 


\section{OPTIMISATION OF PROCESS PARAMETERS IN KENAF/POLYPROPYLENE COMPOSITES IN CONNECTION MOULDING}

The highest Impact strength of $16.54 \mathrm{KJ} / \mathrm{m}^{2}$ is achieved with $80: 20$ blend at $180^{\circ} \mathrm{C}, 7 \mathrm{Mpa}$ pressure and 30 minutes duration. The tensile and flexural strength is the highest at the blend ratio of 65:35 whereas the Impact strength increases with the increase kenaf content up to $80 \%$.

\section{REFERENCES}

1. AK Mohanty, MA Khan, S Sahoo, G Hinrichsen, "Effect of chemical modification on the performance of biodegradable jute yarn-Biopol composites,"Journal of Material Science, vol.35 (10), pp.2589-2595, 2000

2. Y Cao, $\mathrm{Y} \mathrm{Wu}$, "Evaluation of statistical strength of bamboo fibre and mechanical properties of fibre reinforced green composites,"Journal of Central South University of Technology, vol.15:564-567, 2008

3. BH Lee, HJ Kim, WR Yu, "Fabrication of long and discontinuous natural fiber reinforced polypropylene bio composites and their mechanical properties,"Fibers Polymers, vol.10 (1):83-90, 2009

4. X Li, LG Tabil, S Panigrahi, "Chemical treatments of natural fiber for use in natural fiber-reinforced composites: a review,"Journal of Polymer and the Environment, vol.15 (1):25-33, 2007

5. G Mehta, AK Mohanty, K Thayer, M Misra, LT Drzal, "Novel bio composites sheet molding compounds for low cost housing panel applications,"Journal of Polymer and the Environment, vol.13 (2):169-75, 2005

6. GM Zakriya, G Ramakrishnan, "Insulation and mechanical properties of jute and hollow conjugated polyester reinforced nonwoven composite,"Energy and Buildings vol.158, pp.1544-1552,2018

7. A Mustafa, MF Bin Abdollah, FF Shuhimi, N Ismail, H Amiruddin, N Umehara, "Selection and verification of kenaf fibres as an alternative friction material using Weighted Decision Matrix method,"Material Design, vol.67:577-82, 2015

8. G Zakriya, G.M., Ramakrishnan, "Jute fiber reinforced polymeric composites in moulded furniture making,"Journal of Advanced Research in Dynamical and Control Systems vol. 9(16),pp1272-1278,2018

9. GM Zakriya, G Ramakrishnan, "Jute and hollow conjugated polyester composites for outdoor \& indoor insulation applications,"Journal of Natural Fibers, vol, 12(3), pp.1-14 2017

10. N Reddy, QR Jiang, YQ Yang, "Biocompatible natural silk fibers from Argema mittrei,"Journal of Bio based Materials and Bio energy, vol.6 (5), pp.558-63, 2012

11. M Zhan, RP Wool, "Mechanical properties of chicken feather fibers,"Polymer Composites, vol.32 (6), pp.937-44, 2011

12. B Madsen, H Lilholt, "Physical and mechanical properties of unidirectional plant fibre composites - an evaluation of the influence of porosity,"Composites Science and Technology, vol.63 (9), pp.1265-1272, 2003

13. FL Matthews, RD, "Rawlings. Composite materials: engineering and science,"Cambridge, England: Wood head publishing, 1999.

14. Nando GB, Gupta BR, "Short fibre-thermoplastic elastomer composites,'In: DeSK, White JR, editors. Short fibre-polymer composites, Cambridge, England: Wood head publishing, pp. 84-115, 1996

15. PA Sreekumar, K Joseph, G Unnikrishnan, S Thomas, "A comparative study on mechanical properties of sisal-leaf fibre-reinforced polyester composites prepared by resin transfer and compression moulding techniques,"Composites Science and Technology, vol.67 (3-4), pp.453-61, 2007
16. LU Devi, SS Bhagawan, S.Thomas, "Mechanical properties of pineapple leaf fiber-reinforced polyester composites,"Journal of Applied Polymer Science, vol.64 (9), pp.1739-1748, 1997

17. J Holbery, D Houston, "Natural-fiber-reinforced polymer composites in automotive applications,"Journal of the Minerals, Metals and Materials Society, vol.58(11), pp.80 86,2006

18. J Summerscales, NPJ Dissanayake, AS Virk, W. A Hall, “ Review of bast fibres and their composites,"Part 1 - fibres as reinforcements, Composites Part A, vol.41 (10), pp.1329-1335, 2010

19. P Chen, C Lu, Q Yu, Y Gao, J Li, X Li, “ Influence of fiber wettability on the interfacial adhesion of continuous fiberreinforced PPESK composite," Journal of Applied Polymer Science, vol.102 (3), pp.2544-2551, 2006

20. XF Wu, YA.Dzenis, "Droplet on a fiber: geometrical shape and contact angle.Acta Mechanica," 185(3-4), pp.21525, 2006

21. AR Sanadi, DF Caulfield, Jacobson RE, "Agro-fiber thermoplastic composites,'In: Paper and composites from agro-based resources. Boca Raton, FL: CRC press, pp. 377-401, 1997

22. P Heidi, M Bo, J Roberts, N Kalle, "The influence of bio composite processing and composition on natural fiber length, dispersion and orientation,"Journal of Material Science and Engineering- A, vol.1 (2), pp.190-198, 2011

23. IB Amor, H Rekik, H Kaddami, M Raihane, M Arous, A.Kallel, Effect of Palm tree fiber orientation on electrical properties of palm tree fiber-reinforced polyester composites,"Journal of Composites Materials, vol.44 (13), pp.1553-68, 2010

24. PJ Herrera-Franco, A Valadez-Gonzalez, "A study of the mechanical properties of short natural-fiber reinforced composites,"Composites Part B, vol.36 (8), pp.597-608, 2005

25. DA Norman, RE Robertson, "The effect of fiber orientation on the toughening of short fiber-reinforced polymers,"Journal of Applied Polymer Science, vol.90 (10), pp.2740-2751, 2003

26. B Baghaei, M Skrifvars, M Salehi, T Bashir, M Rissanen,P Nousiainen, "Novel aligned hemp fibre reinforcement for structural bio composites: porosity, water absorption, mechanical performances and visco elastic behaviour,"Composites Part A, vol.61), pp.1-12, 2014

27. M-P Ho, H Wang, J-H Lee, C-K Ho, K-T Lau, J Leng, et al, "Critical factors on manufacturing processes of natural fibre composites,"Composites Part B, vol.43 (8), pp.35493562,2012

28. E Bodros, I Pillin, N Montrelay, C Baley, "Could biopolymers reinforced by randomly scattered flax fibre be used in structural applications?," Composite Science and Technology, vol.67 (3), pp.462-470, 2007

29. L Jiang, G Hinrichsen, "Flax and cotton fiber reinforced biodegradable polyester amide composites, 1 manufacture of composites and characterization of their mechanical properties," Angewandte Makromolekulare Chemie, vol.268, pp.13-17,1999

30. K Van de Velde, P Kiekens, "Effect of material and process parameters on the mechanical properties of unidirectional and multidirectional flax/polypropylene composites,"Composite Structures, vol.62 (3-4), pp.443448,2003 
31. A Hao, H Zhao, JY Chen, " Kenaf/polypropylene nonwoven composites: the influence of manufacturing conditions on mechanical, thermal, and acoustical performance,"Composites Part B,vol. 54, pp.44-51,2013

Mr.R.Varadaraju was born in the year 1961 in India. $\mathrm{He}$ is qualified in B.Tech (Textile Technology) in 1983 and M.Tech (Textile Technology) in1995 from PSG college of Technology, Coimbatore; India.

Mr.R.Varadaraju has over 36 years of experience in managing Textile production process research and teaching in Textile Technology. His areas of interest are clothing comfort, knitting, fibre science, composites, and general management. Currently he is doing a research on natural fibre composites. Presently working as an Assistant Professor -III in the Department of Fashion Technology, Kumaraguru College of Technology, Coimbatore, India

Dr.J.Srinivasan was born in the year 1961 in India. He is qualified in $\mathrm{PhD}$ (Textile Technology) from Indian Institute of Technology, New Delhi; India in1991and PDF from Japanese University in 1996.

Dr.J.Srinivasanhas over 34 years of experience in industry Research and Teaching. His areas of interest are clothing comfort, yarn and fabric manufacture and quality control, presently working as a Professor and Head of the Department of Textile Technology, Kumaraguru College of Technology. Coimbatore, India

Dr.J.Srinivasan has received the fellowship award and outstanding textile engineer award from the Institution of engineers (India) 